\title{
Seasonal variation in the reproductive activity of male goats raised under tropical climate conditions
}

\author{
Júlio César Oliveira Dias ${ }^{1^{*}}$, Cristina Mattos Veloso ${ }^{2}$, Madriano Christilis da Rocha Santos ${ }^{1}$, \\ Carlos Thiago Silveira Alvim Mendes de Oliveira' ${ }^{1}$, Camila Oliveira Silveira ${ }^{3}$, Erick Iglesias ${ }^{2}$, \\ Paula Piccolo Maitan ${ }^{3}$, Letícia Maria Pereira Sanglard ${ }^{4}$
}

\footnotetext{
1 Universidade Federal de Viçosa, Programa de Pós-graduação em Zootecnia, Viçosa, MG, Brazil.

2 Universidade Federal de Viçosa, Departamento de Zootecnia, Viçosa, MG, Brazil.

${ }^{3}$ Universidade Federal de Viçosa, Programa de Pós-graduação em Medicina Veterinária, Viçosa, MG, Brazil.

${ }^{4}$ Universidade Federal de Viçosa, Departamento de Medicina Veterinária, Viçosa, MG, Brazil.
}

\begin{abstract}
This study analyzed seasonal variations in the testes, the concentration of sex hormones, the parameters of fresh and thawed semen, and the sexual behavior of male Alpine goats from a temperate region in a tropical climate and possible interference with fertility. The maximum and minimum temperature and luminosity were recorded daily, while seminal, hormonal, and behavioral assessments were carried out every fortnight. The maximum and minimum temperature $\left({ }^{\circ} \mathrm{C}\right)$ and luminosity $(\mathrm{h})$ were recorded daily always at $17.00 \mathrm{~h}$. The scrotal circumference $(\mathrm{cm})$, testicular volume $(\mathrm{mL})$, volume $(\mathrm{mL})$, appearance (creamy, milky, aqueous) and coloration (white, white-yellowish, and yellowish) seminal, turbulence or mass movement ( 0 to 5 ), progressive spermatic motility ( 0 to $100 \%$ ), spermatic force ( 0 to 5 ), concentration (spermatozoids $/ \mathrm{mL}$ ), spermatic pathologies, hypoosmotic test (\%), serum levels of FSH (mUI/mL), LH ( $\mathrm{mUI} / \mathrm{mL})$, testosterone (ng/mL), and sexual behaviors were carried out every fortnight. There was a difference between the scrotal circumference evaluated monthly, testicular volume, volume and concentration of fresh semen, sperm vigor of the thawed semen, serum levels of testosterone, FSH and LH, and some sexual behaviors. Thus, the changes that occur in the quantity and quality of sperm, in the hormonal profile, and in sexual behaviors should not be regarded as an impediment to the use of male Alpine goats in tropical climates throughout the year. These variations do not lead to changes in the semen that may compromise the fertility of these animals.
\end{abstract}

Key Words: gonadotropins, semen quality, sexual behavior, testosterone

\section{Introduction}

The reproductive seasonality is a phenomenon influenced mainly by annual variations in the photoperiod, which increase the proportionally to latitude such that reproductive and non-reproductive seasons are well defined among seasonal species (Abecia et al., 2012). However, in tropical regions, other ambient factors such as ambient temperature, relative air humidity, rain distribution, and nutrition also seem to have effects on reproductive physiology in seasonal animals (Rosa and Bryant, 2003).

The seasonal characteristics of reproduction are expressed with high intensity in females that have

Received: August 30, 2015

Accepted: October 19, 2016

*Corresponding author: diasjuliovet@yahoo.com.br

http://dx.doi.org/10.1590/S1806-92902017000300003

How to cite: Dias, J. C. O.; Veloso, C. M.; Santos, M. C. R.; Oliveira, C. T. S. A. M.; Silveira, C. O.; Iglesias, E.; Maitan, P. P. and Sanglard, L. M. P. 2017. Seasonal variation in the reproductive activity of male goats raised under tropical climate conditions. Revista Brasileira de Zootecnia 46(3):192-201.

Copyright (C) 2017 Sociedade Brasileira de Zootecnia. This is an Open Access article distributed under the terms of the Creative Commons Attribution License (http://creativecommons.org/licenses/by/4.0/), which permits unrestricted use, distribution, and reproduction in any medium, provided the original work is properly cited. a period during which they are apt for reproduction (reproductive season) or are not apt for reproduction (non-reproductive season) (Goodman and Inskeep, 2006), while spermatogenesis and sexual activity are constant in males (Pelletier and Almeida, 1987). Among the main characteristics with seasonal changes that can be observed in males are the changes in sexual behavior (libido), testicular size, spermatogenesis, and hormonal secretion (Kafi et al., 2004; Zamiri and Khodaei, 2005).

Exploring the influence of variations in the ambience on dairy goat breeds, such as Alpine, Saanen, Toggenburg, and Anglo-Nubiana, is necessary, because they are the main breeds from temperate regions that are utilized in tropical regions (Gonçalves et al., 2001). In relation to male goats, greater knowledge of their reproductive variations during the year can help with breeding and husbandry decisions. Thus, it can define the period of the year during which the semen has the best parameters for cryopreservation (Zamiri et al., 2010), which can consequently increase reproductive indexes while maintaining an adequate male:female proportion and also allow for a decrease in the maintenance costs associated with a reduction in the number of breeding (Roca et al., 1992; Barkawi et al., 2006). Moreover, males 
with better sexual behaviors in high temperature conditions can be selected for the development of breeds that are adapted to tropical climates (Pacheco and Quirino, 2010).

The objective of this study was to analyze the seasonal variation in testicular biometry, semen parameters, concentration of testosterone, follicle-stimulating (FSH) and luteinizing (LH) hormones, as well as the sexual behavior of male Alpine goats in tropical climate conditions and possible interference with fertility.

\section{Material and Methods}

All procedures of animal handling were approved by the local Ethics Committee for Animal Use (case no. 32/2013) and were performed according to the Ethics principles of animal experimentation as established by the Brazilian Animal Experimentation College and the current law.

The animals were housed in Viçosa, Minas Gerais, Brazil ( $649 \mathrm{~m}$ of altitude, under the latitude of $20^{\circ} 45^{\prime} 20^{\prime \prime} \mathrm{S}$ and longitude $42^{\circ} 52^{\prime} 40^{\prime \prime} \mathrm{W}$ ). The average annual temperature is $20.9^{\circ} \mathrm{C}$, with an average annual precipitation index of $1,221 \mathrm{~mm}^{3}$ and a highland tropical climate, Cwa type (dry winter and wet summer), based on the weather classification of Köeppen-Geiger. The experimental period was 12 months (from March 2012 to March 2013) and was comprised of the four seasons of the year - autumn (from 20th March to 20th June), winter (from 21th June to 21th September), spring (22th September to 20th December), and summer (21th December to 19th March).

Four clinically healthy male Alpine goats with an average age of $3.4 \pm 1.9$ years were selected and maintained under natural lighting conditions. The animals were housed in covered individual pens with an uncovered exercise area (solarium) where they had free access to solar radiation. The animals received corn silage, a protein and energy concentrate, as well as free access to mineral salt and water, thereby meeting the nutritional requirements of goats according to the National Research Council (NRC, 2007).

The values for brightness from the region where the experiment was performed were acquired from the National Observatory (ON 2013) and the maximum and minimum ambient temperatures $\left({ }^{\circ} \mathrm{C}\right)$ were measured every day at $17.00 \mathrm{~h}$ using a maximum and minimum digital thermo hygrometer $\left(\operatorname{Incoterm}^{\circledR}\right)$, which was installed at half the height of the animals.

Blood samples were collected every fortnight at $7.00 \mathrm{~h}$ by jugular venipuncture in $10-\mathrm{mL}$ tubes without anticoagulant, which were then immediately centrifuged at $1500 \times g$ over $10 \mathrm{~min}$, and the blood serum was then stored at $-20^{\circ} \mathrm{C}$. The assays for dosage of testosterone $(\mathrm{ng} / \mathrm{mL}), \mathrm{FSH}(\mathrm{mUI} / \mathrm{mL})$, and $\mathrm{LH}(\mathrm{mUI} / \mathrm{mL})$ were performed by chemiluminescence through the immune-enzymatic technique while using the commercial kits Beckman Coulter ${ }^{\circledR}$ (Beckman Coulter, USA) and the Access ${ }^{\circledR}$ equipment (Beckman Coulter, USA) according to specifications of the manufacturer.

The testicles of the goats were measured every fortnight during the experimental period with animals in breeding period before semen collection. The testicles were gently pulled by the distal portion of the scrotum and, with a flexible tape, the scrotum circumference $(\mathrm{cm})$ was measured at the largest longitudinal region. There was no correction made for the scrotal skin thickness. The width (medium-side; $\mathrm{cm}$ ) and the length (dorsoventral; $\mathrm{cm}$ ) of each testicle were measured with a caliper rule while excluding the head, body, and tail of the epididymis. The testicular volumes were obtained using the following formula: $\mathrm{TV}=0.5236(\mathrm{TL})(\mathrm{TW})^{2}$, based on the equation by Bailey et al. (1998), in which TV = testicular volume, TL = testicular length, and TW = testicular width.

Sexual behavior during semen collection was observed while considering the following variables: reaction time (period between the introduction of the goat in the collection room with its observation of the female in estrus and ejaculation in the artificial vagina); act of smelling and licking the non-genital region of the female; Flehmen reflex; act of knocking and scraping the hull on the floor; kicking and knocking of the female; emission of characteristic sounds; externalization and retraction of the tongue; penis erection and exhibition; breeding reflex (followed by contraction of the posterior region of the male with or without penis exposure); number of false breeding; and sexual interest after breeding (service). Service was defined as a breeding followed by introduction of the penis in the artificial vagina and ejaculation characterized by a pelvic impulse with head thrown back, followed or not by a short period during which time the goat did not show an interest in the female (refractory period).

Semen collection of the animals was performed every fortnight, always in the morning, during all experimental periods using an artificial vagina with water at $40-42{ }^{\circ} \mathrm{C}$. In a squeeze chute for goats, females in natural or induced estrus during the non-reproductive season were used as dummies. The collection tube $(15 \mathrm{~mL})$ was plastic, transparent, conic, graduated, and protected from the light with aluminum foil.

Two collections from each animal were performed in an interval of ten minutes and after the formation of a pool, the semen was taken immediately to the laboratory for analysis. In all ejaculates, the volume $(\mathrm{mL})$, appearance ( 1 = creamy, 2 = milky, and $3=$ aqueous $)$, coloration $(1=$ 
white, 2 = white-yellowish, and 3 = yellowish), turbulence or mass movement ( 0 to 5 ), progressive spermatic motility (0 to $100 \%$ ), spermatic force ( 0 to 5 ), concentration (spermatozoids $/ \mathrm{mL}$ ), and spermatic pathologies were evaluated. In the collection tubes, volume, aspect, and coloration were verified macroscopically immediately after the collection according to Ax et al. (2004). The evaluation of turbulence was performed by depositing a drop of semen $(10 \mu \mathrm{L})$ in a pre-warmed blade $\left(37^{\circ} \mathrm{C}\right)$, with subsequent observation achieved by using a phase contrast optical microscope at $100 \mathrm{X}$ to classify the sample on a scale from 0 to 5 , in which 0 was the absence of wave movements and 5 was the maximum value of this parameter. To perform the evaluation of spermatic motility and force, $10 \mu \mathrm{L}$ of semen were homogenized with $100 \mu \mathrm{L}$ of Botubov ${ }^{\circledR}$ diluent (Botupharma) and a $10-\mu \mathrm{L}$ aliquot was removed. The observation was made by using a phase contrast optical microscope at $200 \mathrm{X}$, while also using pre-warmed blades and coverslips $\left(37^{\circ} \mathrm{C}\right)$. For motility, subjective percentage grades from 0 to $100 \%$ were attributed to the samples in relation to the amount of total mobile spermatozoids. While for force, values from 0 to 5 were attributed to the samples according to the intensity and speed of movement. The concentration of spermatozoids in the collected semen was determined by using the Neubauer chamber after dilution (1:200) of the sample, while the spermatic morphology was determined by evaluating 100 spermatozoids while using a phase contrast optical microscope (1000X) according to criteria adopted by Blom (1973) for total abnormalities.

Semen samples were diluted in a commercial kit TRISegg yolk containing glycerol (Botubov ${ }^{\circledR}$, Botupharma), which was pre-warmed $\left(37^{\circ} \mathrm{C}\right)$ and had a final concentration of $2.00 \times 10^{6}$ spermatozoids $/ \mathrm{mL}$. Afterwards, the diluted semen was packed in 0.25 -mL plastic straws $\left(\mathrm{IMV}^{\circledR}\right)$, which were maintained in a freezer at $5^{\circ} \mathrm{C}$ for $3 \mathrm{~h}$.

After the cooling period, the straws were placed over the liquid nitrogen vapor in a horizontal position in a stainless steel support grid $\left(\right.$ Botupharma $\left.^{\circledR}\right)$. The straws remained at $5 \mathrm{~cm}$ from liquid nitrogen for $20 \mathrm{~min}$ and then they were immersed in liquid nitrogen and packed in identified racks to be stored in cryogenic containers until further evaluation.

The straws were thawed in a water bath at $37{ }^{\circ} \mathrm{C}$ for $30 \mathrm{~min}$ and the content was transferred to a $1.5-\mathrm{mL}$ plastic tube $\left(\right.$ Eppendorf $\left.{ }^{\circledR}\right)$, from which a $10-\mu \mathrm{L}$ aliquot was removed for analysis of spermatic motility and spermatic force parameters according to the methods described for fresh semen. For the performance of the hypoosmotic test, which evaluates the functionality of the plasmatic membrane, a $50-\mu \mathrm{L}$ aliquot of thawed semen was removed and transferred to a $1.5-\mathrm{mL}$ plastic tube (Eppendorf ${ }^{\circledR}$ ) containing $1 \mathrm{~mL}$ of hypoosmotic solution (fructose solution at $100 \mathrm{mOsm} / \mathrm{L}$ ), and was then incubated in a water bath at $37^{\circ} \mathrm{C}$ for $30 \mathrm{~min}$. After the end of the incubation, $500 \mu \mathrm{L}$ of saline formaldehyde was added for subsequent counting of 100 cells by using an optical microscope with a magnification of 1000X. Spermatozoids with functional membranes were considered those that suffered tail folding during incubation (Bittencourt et al., 2005).

Data were analyzed by the SAS software (Statistical Analysis System, version 9.0). The quantitative variables were evaluated by variance analysis while considering the effect of animal and while using the PROC GLM; the averages were compared by the Ryan-Einot-GabrielWelsh test. The qualitative variables were analyzed by the Kruskal-Wallis test and the PROC NPAR1WAY. Data of sexual behavior were compared between the reproductive (March to August) and the non-reproductive seasons (September to February) by the exact Fisher test (PROC FREQ). The correlations among quantitative variables were evaluated by simple Pearson correlation and the Spearman correlation (PROC CORR) was utilized among the qualitative variables. Data were presented as mean \pm standard error of the mean and the adopted significance was $\alpha=0.05$.

\section{Results and Discussion}

The average difference in the incidence of light between months with greater (December) and less (June) amounts of light was $2.48 \mathrm{~h}$ (Figure 1). This means that there is an increased luminous period during periods of spring and summer and a decrease in autumn and winter (ON, 2013). Goats and some sheep breeds are considered short-day seasonally polyestrous breeders, because the females start their sexual activity (reproductive season) in response to the decreasing length of day, while an increasing length of day ceases the reproductive period (non-reproductive season) (Abecia et al., 2012). The average difference in the incidence of light of $2.48 \mathrm{~h}$ was enough to allow for seasonality in goats in the region studied. In the region, we verified that the reproductive season of females occurs from March to August, which is comprised of the end of summer, autumn, and the beginning of winter.

The scrotal circumference $(\mathrm{cm})$ presented a positive correlation with the maximum temperature $(r=0.48)$ and thus, there were greater values from September to February $(\mathrm{P}<0.05)$, which comprise spring and summer (non-reproductive season) (Table 1 and Figure 2). Barkawi et al. (2006), when working in Egypt (30 $\left.0^{\circ} 1^{\prime} \mathrm{N}\right)$, also found 
greater values for scrotal circumference during spring and summer, while Coloma et al. (2011) and Santiago-Moreno et al. (2013), when working in higher latitudes $\left(40^{\circ} 25^{\prime} \mathrm{N}\right.$ - Spain), found greater values during summer and autumn, which overlap the reproductive season of females. Also, a gradual increase in the measurements of the left and right testicular volumes were observed in this study in September $(\mathrm{P}<0.05)$, during which we observed the absence of females in estrus.

The macroscopic (volume, coloration, and appearance) and microscopic parameters (turbulence, spermatic motility, spermatic force, concentration, and total abnormalities) of the semen can help with the analysis of semen parameters for processing and in the decision regarding the use of in vivo or in vitro.

The semen volume of goats is $1.0 \mathrm{~mL}$ on average, varying from 0.5 to $1.2 \mathrm{~mL}$ (Ax et al., 2004). The average volume that was obtained by Santos et al. (2006) for adult Alpine animals and recommended by the Colégio Brasileiro de Reprodução Animal (CBRA, 2013) is $0.8 \mathrm{~mL}$. Karagiannidis et al. (2000) worked with Alpine goats and verified a difference in the semen volume of $0.33 \mathrm{~mL}$ between the reproductive $(1.42 \mathrm{~mL})$ and non-reproductive seasons $(1.09 \mathrm{~mL})$. In this study, a pool of two successive semen collections with an interval of $10 \mathrm{~min}$ was created and the lowest values of semen volume were observed during the reproductive season (Figure 3 ), with average correlations of $\mathrm{r}=0.35$ and $\mathrm{r}=0.33$ for scrotal circumference and testicular volume, respectively $(\mathrm{P}<0.05)$.

The semen coloration and appearance did not present differences among the monthly averages $(\mathrm{P}>0.05)$ and, according to Mies Filho (1987) and Ax et al. (2004), when analyzed together, these parameters can be indicators of spermatic concentration in ruminants. The greatest semen

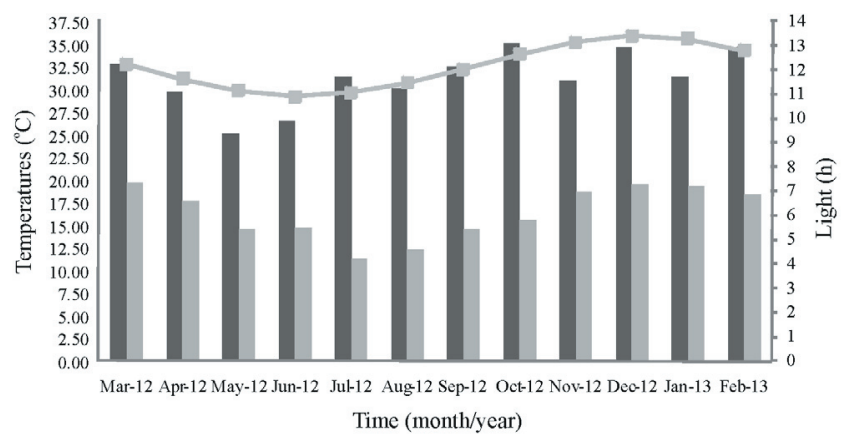

Maximum temperatures $\left({ }^{\circ} \mathrm{C}\right)=$ Minimum temperatures $\left({ }^{\circ} \mathrm{C}\right)-1-$ Light $(\mathrm{h})$

Figure 1 - The average maximum and minimum temperatures $\left({ }^{\circ} \mathrm{C}\right)$ and light $(\mathrm{h})$ during the trial period. dilution is due to greater semen plasma production, which for goats naturally has as a yellowish coloration (Ax et al., 2004). In this study, we observed that the more intense the yellowish coloration (more semen plasma), the greater the aqueous aspect $(r=0.40)$ and the lower the spermatic concentration $(r=-0.43)$ of the collected semen. Moreover, the observation of spermatic coloration can help diagnose pathology in the male reproductive system based on the presence of blood, pus, and urine in the newly collected semen (Ax et al., 2004).

The turbulence, or mass movement ( 0 to 5 ), that occurs in fresh semen of ruminants is characterized by movements such as waves; in this study, these movements correlated positively with the motility $(\mathrm{r}=0.62)$, the spermatic force $(r=0.55)$, and spermatic concentration $(r=0.38)$.

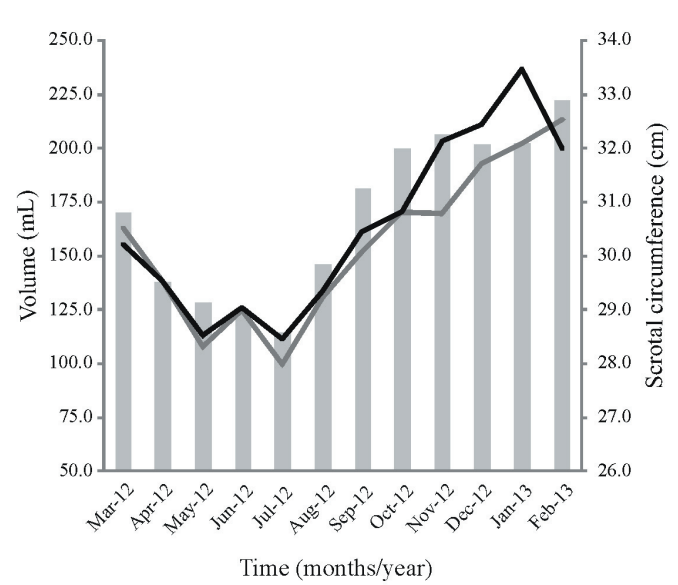

- Scrotal circumference $(\mathrm{cm})$ — Testes left volume $(\mathrm{mL})$ — Testes right volume $(\mathrm{mL})$

Figure 2 - The monthly variations in scrotal circumference $(\mathrm{cm})$ and volume $(\mathrm{mL})$ of the left and right testicles of male Alpine goats in highland tropical climate conditions.

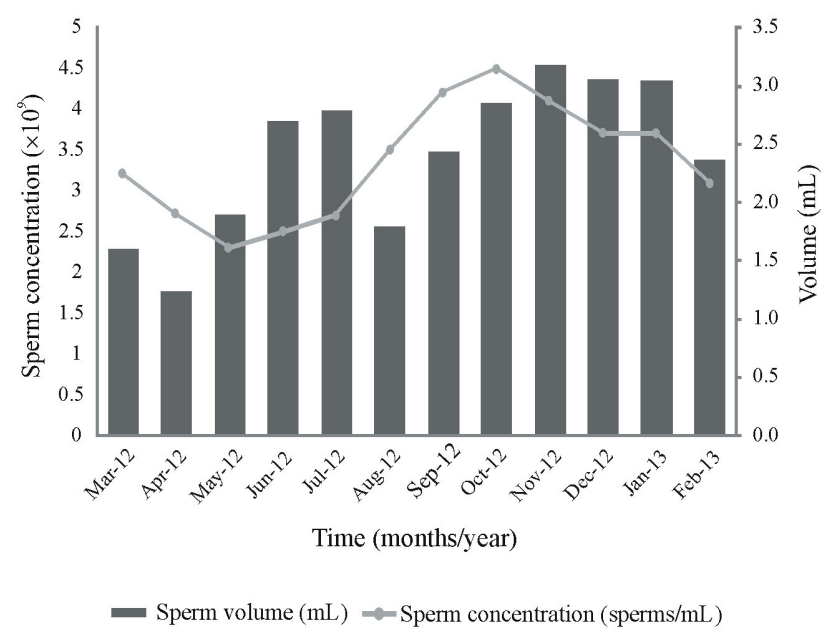

Figure 3 - The averages of the volume $(\mathrm{mL})$ and semen concentration (sperms $/ \mathrm{mL}$ ) of male Alpine goats in highland tropical climate conditions. 


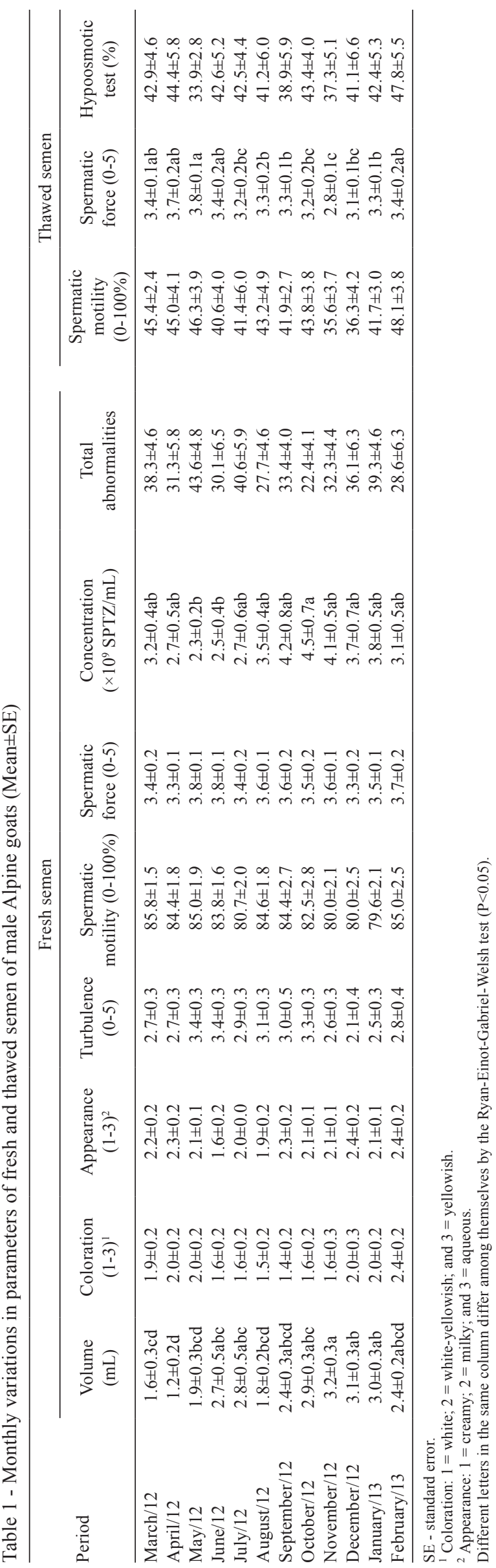

The monthly averages did not present differences during this experiment and were close to the minimum value recommended by the CBRA (2013) and that has been verified by Nunes et al. (1983), which are 3.0 and 3.5 respectively. Yet, it can be highlighted that there were negative correlations obtained between the turbulence and other semen parameters: volume $(r=-0.20)$, appearance $(\mathrm{r}=-0.33)$, and coloration $(\mathrm{r}=-0.41)$. Thus, with a greater dilution, the aqueous aspect and the yellowish coloration were more intense and there was a greater amount of semen plasma in relation to the amount of spermatozoids, which caused lower turbulence.

The progressive rectilinear spermatic motility is represented by the percentage of total mobile progressive spermatozoids, while the spermatic force is the quality (intensity) of the movement of spermatic cells (Castelo et al., 2008). In this study, the progressive motility (0$100 \%)$ and the force $(0-5)$ did not present differences $(\mathrm{P}>0.05)$ among the monthly means and were within the minimum values recommended by the CBRA (2013) for fresh semen of goats, which is $80 \%$ for motility and 3 for spermatic force. The same finding was verified by Coloma et al. (2011), who did not observe differences among the evaluated months either, although they were greater than the values obtained by Santiago-Moreno et al. (2013). The motility and spermatic force are the main and most common parameters utilized in semen evaluation to predict semen quality because of their positive correlation with semen fertilization (Correa et al., 1997).

The average monthly values verified in this study for the spermatic concentration during the experimental period were similar to those observed by Castelo et al. (2008) and Aller et al. (2012), who described a concentration varying from 2.5 to $5.0 \times 10^{9}$ spermatozoids $/ \mathrm{mL}$ for goats as standard. These values were also above the minimum recommended by the CBRA (2013) of $2 \times 10^{9}$ spermatozoids $/ \mathrm{mL}$.

The progressive rectilinear spermatic motility $(0-100 \%)$ of thawed semen did not present differences $(\mathrm{P}<0.05)$ among the average monthly values, varying from 36.3 to $48.1 \%$. This was different from the spermatic force (0-5), which varied from 2.8 to 3.8 after the thawing process $(\mathrm{P}>0.05)$. The values obtained for these parameters were greater than those verified by Coloma et al. (2011) and also above those recommended by the CBRA (2013) with the minimum of $30 \%$ for motility and 2 for force; however, the values were lower than those obtained by Bitencourt et al. (2005).

The processes for semen cryopreservation (dilution, freezing, and thawing) are responsible for important lesions in the spermatozoids, mainly in the plasmatic membranes 
(Holt, 2000). The injuries that occurred in the spermatic cells from effects of temperature and/or osmolarity result in a 50\% decrease of motility in fresh semen (Amman and Pickett, 1987; Thomas et al., 1998), which was observed in this study. Moreover, the morphological and biochemical changes in the semen can also alter the metabolism and production of adenosine triphosphate in the mitochondria of the intermediate piece of the spermatozoid, and thus affect the spermatic force.

Of the ambient variables, high ambient temperatures are those that can influence semen quality the most because they alter the epididymal maturation process, thereby compromising the structures of the plasmatic membrane of the spermatozoids (Huang et al., 2000) and thus decreasing the semen quality after thawing. The hypoosmotic test (\%) evaluates the functionality of plasmatic membranes of spermatozoids and has a positive correlation with progressive spermatic motility, as observed by Martins et al. (2006) and Lodhi et al. (2008), who found $r=0.28$ and $r=0.65$, respectively. In this study, the hypoosmotic test results (33.9-47.8\%) of thawed semen did not present a difference among the monthly averages and were close to those verified by Santos et al. (2006), but were greater than those obtained by Bittencourt et al. (2005), which were 39 and $17 \%$, respectively. Thus, based on the absence of significant changes in the averages of progressive spermatic motility and the hypoosmotic test during all months of the year, it can be inferred that the ambient did not change the spermatic plasmatic membranes or lead to a decrease in semen quality.

In the analyzes of the sperm morphology of fresh semen (total abnormalities) no difference was found between the months $(\mathrm{P}>0.05)$ during the experimental period (Table 1). However, Coloma et al. (2011) and Santiago-Moreno et al.
(2013) verified differences along the year, during which autumn and spring had the lowest (30 and 24.1\%) and the greatest (80 and $61.5 \%$ ) spermatic pathology percentages, respectively. According to Sarlós et al.(2013), this difference can occur because there is a negative correlation between seasonality and spermatic abnormalities $(r=-0.55)$. In other words, during the reproductive season, there is a lower occurrence of defective spermatozoid indexes, which can compromise spermatic quality and affect the efficiency of fertilization. However, these studies were conducted in higher latitude regions $\left(>40^{\circ} \mathrm{N}\right)$, where the seasonality of the photoperiod has a large influence on reproductive physiology, which is different from the regions where this study was conducted $\left(20^{\circ} \mathrm{S}\right)$.

The seasonal reproductive characteristics are expressed more intensely in goats such as Alpines from latitudes higher than $35^{\circ} \mathrm{N}$ or $35^{\circ} \mathrm{S}$ (Avdi et al., 2004; Sarlós et al., 2013). These animals from temperate climates have reproductive seasons during lower light intensity periods, i.e., during the end of summer, autumn, and winter (Abecia et al., 2012). In males, these reproductive changes are lower and do not contribute to an interruption in gametogenesis and sexual activity, as is the case in females (Pelletier and Almeida, 1987).

According to Baril et al. (1993), the testicles of a male adult goat are influenced by breed, season, and nutritional status. In this experiment, animals from the same breed were utilized and the feeding did not suffer from changes during the experimental period, with the photoperiod as the unique variable modified along the year (Figure 1). The majority of the testicular and semen parameters did not present differences $(\mathrm{P}>0.05)$ among the evaluated months and therefore, in males, the reproductive seasonality influenced by photoperiod was not observed with greater intensity, as was the case for females, which had the expression of estrus

Table 2 - Monthly variations in the hormones FSH $(\mathrm{mUI} / \mathrm{mL}), \mathrm{LH}(\mathrm{mUI} / \mathrm{mL})$, and testosterone $(\mathrm{ng} / \mathrm{mL})$ of male Alpine goats in highland tropical climates $(\mathrm{Mean} \pm \mathrm{SE})$

\begin{tabular}{|c|c|c|c|}
\hline Period & FSH (mUI/mL) & LH (mUI/mL) & Testosterone $(\mathrm{ng} / \mathrm{mL})$ \\
\hline $\operatorname{March} / 12$ & $0.45 \pm 0.16 \mathrm{ab}$ & $1.29 \pm 0.42 \mathrm{ab}$ & $14.17 \pm 0.88 \mathrm{ab}$ \\
\hline April/12 & $0.13 \pm 0.05 b$ & $0.40 \pm 0.24 \mathrm{bc}$ & $16.95 \pm 0.65 \mathrm{a}$ \\
\hline May/12 & $0.10 \pm 0.05 b$ & $0.37 \pm 0.25 b c$ & $9.54 \pm 1.43 \mathrm{bcd}$ \\
\hline June/12 & $0.16 \pm 0.07 b$ & $0.54 \pm 0.25 b c$ & $5.62 \pm 1.01 \mathrm{cde}$ \\
\hline July/12 & $0.07 \pm 0.03 b$ & $0.38 \pm 0.25 b c$ & $3.46 \pm 1.25 \mathrm{e}$ \\
\hline August/12 & $0.14 \pm 0.03 b$ & $0.23 \pm 0.10 \mathrm{c}$ & $2.03 \pm 0.24 \mathrm{e}$ \\
\hline September/12 & $0.06 \pm 0.02 b$ & $0.25 \pm 0.16 b c$ & $3.07 \pm 0.58 \mathrm{de}$ \\
\hline October/12 & $0.10 \pm 0.04 b$ & $0.36 \pm 0.17 b c$ & $2.83 \pm 0.49 \mathrm{e}$ \\
\hline November/12 & $0.10 \pm 0.04 b$ & $0.41 \pm 0.20 b c$ & $4.75 \pm 1.34 \mathrm{cde}$ \\
\hline December/12 & $0.12 \pm 0.07 \mathrm{~b}$ & $0.32 \pm 0.20 b c$ & $3.89 \pm 1.26 \mathrm{de}$ \\
\hline January/13 & $0.10 \pm 0.04 \mathrm{~b}$ & $0.35 \pm 0.15 b c$ & $10.22 \pm 1.83 b c$ \\
\hline February/13 & $0.54 \pm 0.19 \mathrm{a}$ & $1.64 \pm 0.55 \mathrm{a}$ & $14.37 \pm 1.81 \mathrm{ab}$ \\
\hline
\end{tabular}

FSH - follicle-stimulating hormone; LH - luteinizing hormone; SE - standard error

Different letters in the same column differ among themselves by the Ryan-Einot-Gabriel-Welsh test $(\mathrm{P}<0.05)$. 
only between March and August. Thus, we suppose that the changes observed from March to August (reproductive season) in the form of decreasing scrotal circumference, testicular volume, and spermatic concentration could be due to the increased number of coverage performed by breeding the herd during this period. However, it is possible that the photoperiod has also influenced the accessory glands, which are responsible for seminal plasma production, and could thus have increased the seminal volume during the reproductive season and decreased the spermatic concentration from May to June (Figure 3).

However, high ambient temperatures can influence morphological and seminal changes in the breeding due to the increase in seminiferous tubules and, consequently, also affect the testicular volume and scrotal circumference (Amman, 1962). In this study, the maximum ambient temperatures were higher in the period from September to February, which is the period when an increase in seminal volume and concentration were also observed, as well as scrotal circumference and testicular volume $(\mathrm{P}<0.05)$. These animals from temperate climate regions can adapt their reproductive physiology to highland tropical climates and thus, the reference values of some parameters, such as scrotal circumference, should be evaluated differently and according to the ambient where they live.

The greatest plasmatic concentrations $(\mathrm{P}<0.05)$ of FSH and LH occurred in February and March and of testosterone, from February to April, or during periods that comprise summer and autumn. The concentrations of these hormones can be influenced mainly by annual photoperiod and proximity of the reproductive season of goats in the regions of the experiment (latitude $20^{\circ} \mathrm{S}$ ), which occurred from March to August. The LH and testosterone presented a negative correlation with light. In other words, the decreasing photoperiod stimulated LH synthesis and, consequently, stimulated testosterone synthesis. Barkawi et al. (2006), Zarazaga et al. (2009), and Coloma et al. (2011), when working with goats in regions with latitudes of $30^{\circ}$ $\mathrm{N}, 37^{\circ} \mathrm{N}$, and $36^{\circ} \mathrm{N}$, respectively, also verified greater values of these hormones during the end of the summer and autumn, which are periods with decreasing photoperiods.

With the reduction in the photoperiod from January $(\mathrm{P}<0.05)$ (Figure 1), melatonin probably began to be synthesized in greater amounts by the pineal gland (Abecia et al., 2012). In goats, this hormone induces the hypothalamus to release the gonadotropin-releasing hormone via pulsatile secretion, which acts on the anterior pituitary and leads to the release of greater amounts of the gonadotropins FSH and LH (Brackett, 2006). In testicles, the follicle-stimulating hormone is responsible for the functionality of the Sertoli cells, which are located inside of the seminiferous tubules and provide structural, nutritional, and functional support for the differentiation and proliferation of germ cells (Sharpe et al., 2003; Brackett, 2006). The LH acts on Leydig cells, which are located in the intertubular tissue and synthesize androgens as their main function (Gardner and Hafez, 2004; Brackett, 2006). Testosterone is the main male hormone and stimulates the final stages of spermatogenesis, contributes to the extension of the life of spermatozoids in the epididymis, and stimulates the development of reproductive organs, secondary sexual characteristics, and libido (Gardner and Hafez, 2004; Brackett, 2006).

The increase in the synthesis of the pituitary hormone and testosterone occurred in advance of the reproductive period of females (Thiéry et al., 2002), which happens at the end of summer, autumn, and at the beginning of winter (from March to August). This early stimulation begins 1 to 1.5 months before females are due to begin their cyclic period, at which time the males have already reached sexual activity and spermatic production. This differential sensitivity to photoperiod is important because, while females in anestrus ovulate a few days after the beginning of hormonal stimulation, males need around 54 days to complete spermatogenesis (Rosa and Bryant, 2003).

According to Sharpe et al. (2003) and Barkawi et al. (2006), the increased testicular volume in the period prior to and during the reproductive season is due to the increase in the area occupied by seminiferous tubules, which is influenced by the hormones FSH and $\mathrm{LH}$ and that are secreted in association with the reduction in the photoperiod, as observed by Coloma et al. (2011) and Santiago-Moreno et al. (2013). In this study, despite the annual variation in the concentrations of $\mathrm{FSH}, \mathrm{LH}$, and testosterone $(\mathrm{P}<0.05)$ (Figure 4), changes were not observed in seminal quality (Table 1; Figure 3) and testicular volume (Figure 2), which are related to these hormones but are also related to greater or lower use of the animals for breeding in coverage.

Salles (2010) reported an increase in the testosterone concentrations during the period of the year with higher ambient temperatures, although Coelho et al. (2008) showed that male goats in heat stress do not present variations in testosterone plasmatic concentrations. According to Barbosa et al. (1999), it is not yet known whether the changes in hormonal synthesis are only influenced by photoperiod or by a combination of other ambient factors (temperature, humidity, etc.).

According to Chemineau et al. (1991), the sexual behaviors of adult males depend mainly on hormonal secretions based on social interactions. Nevertheless, 
Azevêdo et al. (2008) stated that the intensity and frequency of male sexual behavior can also be influenced by ambient factors and not exclusively by sexual hormones.

The real reproductive ability of males can be indirectly determined by libido, which is the degree of interest of the male to copulate (Chenoweth, 1981). According to the classification of Chemineau et al. (1991), for small ruminants, libido can be evaluated by reaction time (seconds). In other words, libido can be evaluated based on the elapsed time between presentation of females to the male and the subsequent ejaculation on a female in estrus; it can be classified as excellent ( $30 \mathrm{~s})$, good ( 31 to $60 \mathrm{~s}$ ), average (61 to $120 \mathrm{~s}$ ), or tolerable (longer than $120 \mathrm{~s}$ ). Thus, as verified by Souza et al. (2007), the libido of the animals in this experiment can be considered good for the reproductive and non-reproductive seasons.

According to Azevêdo et al. (2008), in tropical climate countries, the libido of small ruminants generally reveals little variation, although it can be influenced by ambient variables such as temperature, rainfall, relative air humidity, insulation, or by a change in the feed offered. Godfrey et al. (1998), when working with sheep from temperate climates in heat stress conditions, observed that there were no changes in behavioral parameters, which reveals the adaptability of breeds to tropical climates. However, in temperate latitude regions, the sexual activity is greater from October (autumn), when there is a decrease in the amount of light, as it stimulates males to synthesize androgens and females to reset their estrous cycle and produce pheromones (Barkawi et al., 2006; Zarazaga et al., 2009).

According to Chemineau et al. (1991), after the male identifies and approaches a female, it evaluates the female receptivity. If the female is in estrus (immobility), the male continues its sequence of pre-coital behavior (courtship) that culminates in copulation. In this study, the sexual behavior

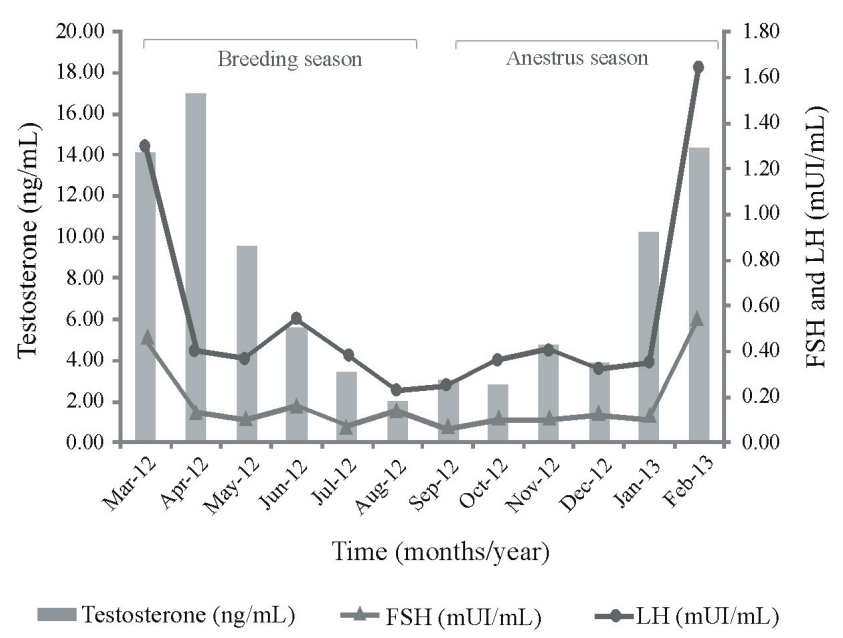

Figure 4 - The averages of the testosterone, FSH (folliclestimulating hormone) and LH (luteinizing hormone) concentration of male Alpine goats in highland tropical climate conditions.

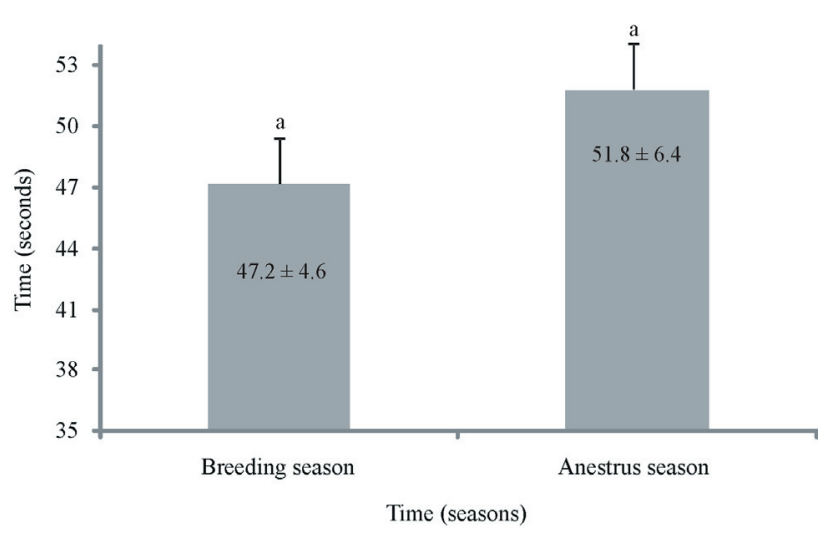

Figure 5 - The averages of the reaction time (seconds) in the breeding and anestrus season of male Alpine goats in highland tropical climate conditions.

Table 3 - Frequency of physiological signals of sexual behavior observed during semen collection in the reproductive and non-reproductive seasons of male Alpine goats in highland tropical climates (Mean $\pm \mathrm{SE})$

\begin{tabular}{|c|c|c|}
\hline \multirow{2}{*}{ Behavior } & \multicolumn{2}{|c|}{ Period } \\
\hline & Reproductive season $(\%)$ & Non-reproductive season $(\%)$ \\
\hline Act of smelling and licking the non-genital region of females & $96.4(53 / 55) \mathrm{a}$ & $98.1(51 / 52) \mathrm{a}$ \\
\hline Flehmen reflex & $18.2(10 / 55) \mathrm{a}$ & $7.7(4 / 52) \mathrm{a}$ \\
\hline Act of beating and scraping the hull floor & $32.7(18 / 55) \mathrm{a}$ & $15.4(8 / 52) \mathrm{b}$ \\
\hline Kicking and knocking of female & $12.7(7 / 55) \mathrm{a}$ & $9.6(5 / 52) \mathrm{a}$ \\
\hline Emission of characteristic sounds & $20.0(11 / 55) \mathrm{a}$ & $17.3(9 / 52) \mathrm{a}$ \\
\hline Externalization and retraction of the tongue & $52.7(29 / 55) \mathrm{a}$ & $26.9(14 / 52) b$ \\
\hline Penis erection and exposure & $54.6(30 / 55) \mathrm{a}$ & $59.6(31 / 52) \mathrm{a}$ \\
\hline Breeding reflex & $76.4(42 / 55) \mathrm{a}$ & $40.4(21 / 52) b$ \\
\hline Breeding without service (or false breeding) & $14.6(8 / 55) \mathrm{a}$ & $5.8(3 / 52) \mathrm{a}$ \\
\hline Sexual interest after breeding (service) & $47.3(26 / 55) \mathrm{a}$ & $42.3(22 / 52) \mathrm{a}$ \\
\hline
\end{tabular}

SE - standard error.

Different letters in the same column differ among themselves by the Ryan-Einot-Gabriel-Welsh test $(\mathrm{P}<0.05)$. 
showed a seasonal variation only in the act of beating and scraping of the hull on the floor, in externalizing and retracting the tongue, and in the breeding reflex (Table 3 ). These behaviors in males can be caused by the pheromones of goats in natural estrus, therefore allowing for greater excitations and the act of pre-copulatory courtship. The presence of the majority of the sexual behaviors during the non-reproductive season can be also due to the fact that the animals were already conditioned to people, the locale, and handling for collection using an artificial vagina, or were adapted to the tropical climate.

Therefore, the greater the latitude of the region, the greater the variation in reproductive parameters of seasonal species will be between reproductive and nonreproductive seasons (Aguirre et al., 2007) (Figure 5) due to the influence of annual photoperiods. When these animals are raised in tropical regions, some physiological characteristics sensitive to decreasing photoperiods, such as the synthesis of gonadotropin hormones, can remain. However, as observed in this study, the proximity to the Ecuador line and consequently, the occurrence of shorter photoperiod variations during the year did not significantly change the seminal quality. Thus, we can consider that the reproductive physiology of animals from temperate regions is adapted to the tropical climate. The occurrence of some variations in seminal quantity and quality, hormone profile, and some sexual behaviors during courtship and copulation should not be considered as an obstacle in the decision on whether to use male Alpine goats in reproductive handling along the year. As verified in other studies (Roca et al., 1992; Karagiannidis et al., 2000; Kafi et al., 2004; Aguirre et al., 2007; Sarlós et al., 2013), the variation in some physiological parameters of male Alpine goats in highland tropical climates (Viçosa, MG - Brazil) throughout the year did not compromise their capacity for fertilization.

\section{Conclusions}

The existence of variations during the breeding seasons in testicular biometry, some seminal parameters (volume and concentration), sexual hormone synthesis, and sexual behavior of male Alpine goats raised in tropical climate conditions should not be considered as an obstacle in the decision to use these animals for breeding throughout the year. These variations may be correlated with the coverage frequency of females and/or the influence of photoperiod, and do not change the semen in a way that could compromise the capacity of fertilization of these animals.

\section{Acknowledgments}

The authors thank Conselho Nacional de Desenvolvimento Científico e Tecnológico (CNPq) for the financial support.

\section{References}

Abecia, J. A.; Forcada, F. and González-Bulnes, A. 2012. Hormonal control of reproduction in small ruminants. Animal Reproduction Science 130:173-179.

Aguirre, V.; Orihuela, A. and Vazquez, R. 2007. Effect of semen frequency on seasonal variation in sexual behavior, testosterone, testicular size and semen characteristics of tropical hair sheep (Ovis aries). Tropical Animal Health and Production 39:271-277.

Aller, J. F; Aguilar, D.; Vera, T.; Almeida, G. P. and Alberio, R. H. 2012. Seasonal variation in sexual behavior, plasma testosterone and semen characteristics of Argentine Pampinta and Corriedale rams. Spanish Journal of Agricultural Research 10:345-352.

Amman, R. P. 1962. Reproductive capacity of dairy bulls. IV. Spermatogenesis and testicular germ cell degeneration. American Journal of Anatomy 110:69-78.

Amman, R. P. and Pickett, B. W. 1987. Principles of cryopreservation and a review of cryopreservation on stallion spermatozoa. Journal of Equine Veterinary Science 7:145-173.

Avdi, M.; Banos, G.; Stefos, K. and Chemineau, P. 2004. Seasonal variation in testicular volume and sexual behavior of Chios and Serres rams. Theriogenology 62:275-282.

Ax, R. L.; Dally, M.; Didion, B. A.; Lenz, R. W.; Love, C. C.; Varner, D. D.; Hafez, B. and Bellin, M. E. 2004. Semen Evaluation. p.365-375. In: Reproduction in Farm Animals. Wiley John \& Sons Incorporated, Nova Jersey.

Azevêdo, D. M. M. R.; Martins Filho, R.; Alves, A. A.; Araújo, A. A. and Lôbo, R. N. B. 2008. Comportamento sexual de ovinos e caprinos machos: uma revisão. PUBVET 2:17, Art. 130.

Bailey, T. L.; Hudson, R. S.; Powe, T. A.; Riddell, M. G.; Wolfe, D. F. and Carson, R. L. 1998. Caliper and ultrasonographic measurements of bovine testicles and a mathematical formula for determining testicular volume and weight in vivo. Theriogenology 49:581-594.

Barbosa, S. B. P.; Martins Filho, R. and Martins, G. A. 1999. Aspectos genéticos e de ambiente em características de crescimento em bovinos de raça Nelore, no estado de Pernambuco. p.147. In: Anais da $36^{a}$ Reunião Anual da Sociedade Brasileira de Zootecnia, Porto Alegre.

Baril, G.; Chemineau, P.; Cognie, Y.; Guerin, Y.; Leboeuf, B.; Orgeur, P. and Vallet, J. C. 1993. Manuel de formation pour l'insémination artificielle chez les ovins et les caprins. FAO, Rome.

Barkawi, A. H.; Elsayed, E. H.; Ashour, G. and Shehata, E. 2006. Seasonal changes in semen characteristics, hormonal profiles and testicular activity in Zaraibi goats. Small Ruminant Research 66:209-213.

Bittencourt, R. F.; Ribeiro Filho, A. L.; Santos, A. D. F.; Chalhoub, M.; Alves, S. G. G.; Vasconcelos, M. F.; Leandro, E. E. S. and Guimarães, J. D. 2005. Use of hipoosmotic test to evaluate the efficacy of different protocols of cryopreservation of the goat semen. Ciência Animal Brasileira 6:213-218.

Blom, E. 1973. The ultra structure of some characteristics sperm defects and a proposal for a new classification of the bull spermiogram. Nordic Veterinary Medicine 25:383-391.

Brackett, B. G. 2006. Male Reproduction in Mammals. p.623-643. In: Dukes' Physiology of Domestic Animals. Comstock Publishing Associates, Ithaca.

Castelo, T. S.; Frota, T. R. and Silva, A. R. 2008. Considerações sobre a criopreservação do sêmen de caprinos. Acta Veterinaria Brasilica 2:67-75. 
CBRA - Colégio Brasileiro de Reprodução Animal. 2013. Manual para exame andrológico e avaliação de sêmen animal. CBRA, Belo Horizonte.

Chemineau, P.; Cagnié, Y.; Guérin, Y.; Orgeur, P. and Vallet, J. C. 1991. Training manual on artificial insemination in sheep and goats. Animal Production and Health Paper. FAO, Rome.

Chenoweth, P. J. 1981. Libido and mating behavior in bulls, boars and rams. A review. Theriogenology 16:155-177.

Coelho, L. A.; Sasa, A.; Bicudo, S. D.; Balieiro, J. C. C. 2008. Plasma concentrations of testosterone, triiodothyronine (T3), and thyroxine (T4) in bucks submitted to heat stress. Arquivo Brasileiro de Medicina Veterinária e Zootecnia 60:1338-1345.

Coloma, M. A.; Toledano-Díaz; Castaño, C.; Velázquez, R.; GómezBrunet, A.; López-Sebastián, A. and Santiago-Moreno, J. 2011. Seasonal variation in reproductive physiological status in the Iberian ibex (Capra pyrenaiaca) and its relationship with sperm freezability. Theriogenology 76:1695-1705.

Correa, J. R.; Pace, M. M. and Zavos, P. P. 1997. Relationships among frozen-thawed sperm characteristics accessed via the rotine semen analysis, sperm functional tests and fertility of bulls in artificial insemination program. Theriogenology 48:721-31.

Gardner, D. L. and Hafez, E. S. E. 2004. Spermatozoa and Seminal Plasma. p.96-109. In: Reproduction in farm animals. Wiley John \& Sons Incorporated, Nova Jersey.

Godfrey, R. W.; Collins, J. R. and Gray, M. L. 1998. Evaluation of sexual behavior of hair sheep rams in a tropical environment. Journal of Animal Science 76:714-717.

Gonçalves, H. C.; Silva, M. A.; Wechsler, F. S. and Ramos, A. A. 2001. Fatores genéticos e de meio na produção de leite de caprinos leiteiros. Revista Brasileira de Zootecnia 30:719-729.

Goodman, R. L. and Inskeep, E. K. 2006. Neuroendocrine control of the ovarian cycle of the sheep. p.2389-2428. In: Physiology of Reproduction. Elsevier, London.

Holt, W. V. 2000. Fundamental aspects of sperm cryobiology: the importance of especies and individual differences. Theriogenology 53:47-58.

Huang, S. Y.; Kuo, Y. H.; Lee, Y. P.; Tsou, H. L.; Lin, E. C. and Lee, W. C. 2000. Association of heat shock protein 70 with semen quality in boars. Animal Reprodution Science 63:231-240.

Kafi, M.; Safdarian, M. and Hashemi, M. 2004. Seasonal variation in semen characteristics, scrotal circumference and libido of Persian Karakul rams. Small Ruminant Research 53:133-139.

Karagiannidis, A.; Varsakeli, S.; Alexopoulos, C. and Amarantidis, I. I. 2000. Seasonal variation in semen characteristics of Chios and Friesian rams in Greece. Small Ruminant Research 37:125-130.

Lodhi, L. A.; Zubair, M.; Qureshi, Z. I.; Ahmad, I. and Jamil, H. 2008. Correlation between hypo-osmotic swelling test and various conventional semen evaluation parameters in fresh nili-ravi buffalo and sahiwal cow bull semen. Pakistan Veterinary Journal 28:186-188.

Martins, L. F.; Pereira, M. C. B.; Guimarães, J. D.; Costa, E. P.; Silveira, T. S.; Torres, C. A. A.; Rodrigues, M. T. and Braz, V. B. 2006. Reproductive performance, soluble proteins of the seminal plasm and hypoosmotic test in male goats of the Alpine breed under controlled mating. Revista Brasileira de Zootecnia 35:1653-1659.

Mies Filho, A. 1987. Inseminação artificial. Sulina, Porto Alegre.

NRC - National Research Council. 2007. Nutrient requirements of small ruminants: Sheep, goats, cervids, and new world camelids. National Academy Press, Washington.
Nunes, J. F.; Riera, G. S.; Silva, A. E. F. D.; Ponce de Leon, B. F. A and Lima, F. A. M. 1983. Características espermáticas de caprinos Moxotó de acordo com a morfologia escrotal. EMBRAPA/ CNPCaprinos, Sobral.

ON - Observatório Nacional. 2013. Anuário interativo do Observatório Nacional. Available at: <http://www.on.br>. Accessed on: Mar. 7, 2013.

Pacheco, A. and Quirino, C. R. 2010. Sexual behavior of ram. Revista Brasileira de Reprodução Animal 34:87-97.

Pelletier, J. and Almeida, G. 1987. Short light cycles induce persistent reproductive activity in Ile-de-France rams. Journal of Reproduction and Fertility. Supplement 34:215-226.

Roca, J.; Martinez, E.; Vazquez, J. M. and Coy, P. 1992. Characteristics and seasonal variations in the semen of Murciano-Granadina goats in the Mediterranean area. Animal Reproduction Science 29:255-262.

Rosa, H. J. D. and Bryant, M. J. 2003. Seasonality of reproduction in sheep. Small Ruminant Research 48:155-171.

Salles, M. G. F. 2010. Parâmetros físiológicos e reprodutivos de machos caprinos Saanen criados em clima tropical. Thesis (D.Sc.). The State University of Ceará, Fortaleza, CE, Brazil.

Santos, A. D. F; Torres, C. A. A.; Fonseca, J. F.; Borges, A. M.; Costa, E. P.; Guimarães, J. D. and Rovay, H. 2006. Reproductive aspects of male goats under an artificial photoperiod exposure. Revista Brasileira de Zootecnia 35:1926-1933.

Santiago-Moreno, J.; Toledano-Díaz, A.; Castaño, C.; Coloma, M. A.; Esteso, M. C.; Prieto, M. T.; Delgadillo, J. A. and LópezSebastián, A. 2013. Photoperiod and melatonin treatments for controlling sperm parameters, testicular and accessory sex glands size in male Iberian ibex: a model for captive mountain ruminants. Animal Reproduction Science 139:45-52.

Sarlós, P.; Egerszegi, I.; Balogh, O.; Molnár, A.; Cseh, S. and Rátky, J. 2013. Seasonal changes of scrotal circumference, blood plasma testosterone concentration and semen characteristics in Racka rams. Small Ruminant Research 111:90-95.

Sharpe, R. M. 2003. Proliferation and functional maturation of Sertoli cells, and their relevance to disorders of testis function in adulthood. Reproduction 125:769-784.

Souza, J. A. T.; Campelo, J. E. G.; Leal, T. M.; Sousa Júnior, A.; Medeiros, R. M. and Macedo, R. C. 2007. Testicular biometry, seminal characteristics, libido and testosterone concentrations in sheep of the Santa Inês breed, maintained on field, in the microrregion of Campo Maior, Piaui. Ciência Veterinária nos Trópicos 10:21-28.

Thiéry, J. C.; Chemineau, P.; Hernandez, X.; Migaud, M. and Malpaux, B. 2002. Neuroendocrine interactions and seasonality. Domestic Animal Endocrionolgy 23:87-100.

Thomas, C. A.; Ganer, D. L.; Dejarnete, J. M. and Marshall, C. E. 1998. Effect of cryopreservation on bovine sperm organelle function and viability as determinated by flow cytometry. Biology and Reproduction 58:786-793.

Zamiri, M. J. and Khodaei, H. R. 2005. Seasonal thyroidal activity and reproductive characteristics of Iranian fat-tailed rams. Animal Reproduction Science 88:245-255.

Zamiri, M. J.; Khalili, B; Jafaroghli, M. and Farshad, A. 2010 Seasonal variation in seminal parameters, testicular size, and plasma testosterone concentration in Iranian Moghani rams. Small Ruminant Research 94:132-136.

Zarazaga, L. A.; Guzmán, J. L.; Domínguez, C.; Pérez, M. C. and Prieto, R. 2009. Effects of season and feeding level on reproductive activity and sêmen quality in Payoya buck goats. Theriogenology 71:1316-1325. 